原 㩼

\title{
新しい非侵襲的動脈硬化測定法としての動脈壁血管開口伝播速度
}

\author{
—血清脂質および動脈硬化指数との関係—
}

新

啓一郎* 美 並 真由美*
渡 辺 文 督* 竹 中

I. 目 的

間接法による血圧測定時にカフ圧がわずかでも収縮期 血圧以下になると, 血流によりカフ圧下の血管の中枢側 が開ロし，血液が末梢側をで運ばれる。この血管開口の 中枢から末梢への伝播は動脈壁の変形によりもたらされ ることが知られて招り，血管壁の粘弾性を反映するもの と考兄られる ${ }^{1,2)}$. この動脈壁血管開口伝播速度 $(\mathrm{OV})$ は，同一被験者に扮いては，運動などによる心拍数拈よ び血圧変化の影響をうけず2)，再現性も良好であること が報告されている2).

また，OV は加齢に伴い低下すること象，さらに，従来 より動脈硬化の指標として用いられている大動脈脈波伝 播速度 $(\mathrm{PWV})$ とは負の相関関係があることも報告さ れて抢り ${ }^{3)}$ ，新しい動脈硬化の指標となりらるものと考 完られる。

本研究では，OV と動脈硬化との関係をさらに検討す るため, OV と動脈硬化指数との関係を正常者あるいは 高脂血症患者で調べた。

\section{II. 対象と方法}

正脂血症あるいは高脂血症患者計 145 例 (男 95 例, 女 50 例，平均年齢 $50.9 \pm 11.2[\mathrm{SD}]$ ） を対象とし，その動脈 硬化指数 $(\mathrm{AI})$ が 2 回の測定により, ともに 3.2 以上の $\mathrm{AI}$ 高値群 (H 群, $\mathrm{n}=56)$ と 2.8 未満の正常群 ( $\mathrm{N}$ 群, $\mathrm{n}=71)$ に分け，両群で動脈壁血管開口伝播速度 (OV) を比較した。また, OV は加㱓に伴い減少することが知ら れているので, 全対象者を 10〜39歳, 40〜59 歳および 60 〜 79歳に分け，それぞれの年齢層で OV と AI, 血清脂質

\footnotetext{
* 東京大学医学部第二内科 原稿受取日：1993 年 7 月 13 日 採用決定日：1994 年 10 月 21 日
}

高 木 正 雄* 石 山明 寛* 克* 小俣 政 男*
扣よび血圧との関係も調べた。一部の対象者では, OVを 同一検査日に 2 回 $(n=17)$, あるいは別々の日に測定し $(\mathrm{n}=9)$ その再現性についても検討した.

24 時間以上のアルコール摂取を禁じ, 14 時間以上の絶 食下の早期に採血し，血清総コレステロール (TC), HDL コレステロール拉よびトリグリセライド (TG) を 測定した。動脈硬化指数 (AI) は次式 (1)により算出し た.

$$
\mathrm{AI}=\begin{aligned}
& (\mathrm{TC}-\mathrm{HDL} \text { コレステロール }) \\
& / \mathrm{HDL} \text { コレステロール }
\end{aligned}
$$

OV はビムスーI (マクター社)を用い上腕動脈にて測 定した ${ }^{2)}$. 詳しくは, 血圧測定用のカフの内周部に高分子 圧電素子膜センサー2 本を $8 \mathrm{~cm}$ 間隔で平行に配置した ものを, センサーの長軸方向が被験者の上腕動脈々直交 するように装着する。測定はスイッチを押すと自動的に 行われ，カフ圧が収縮期血圧以上に加圧されたあと，1心 拍について 2 3 mmHg の速度で減圧され，カフ加圧が 収縮期血圧よりわずかに低下した時点で血液が中枢側よ

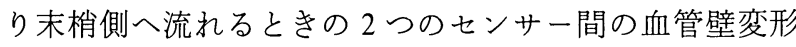
の伝播速度 $(\mathrm{OV})$ が，2 2 センサー間の距離 $(0.08 \mathrm{~m}) /$ 時 間 $(\mathrm{sec})$ で算出される。

測定值は平均值士標準偏差 (SD) で表した。統計学的 解析は Student $の$ unpaired $\mathrm{t}$ 検定にて行い，相関関係は 相関係数 $\mathrm{r}$ 算出し, $\mathrm{p}<0.05$ の場合に有意であると考兄 た.

\section{III. 結 果}

Table 1 に N 群と H 群の臨床背景を示した。 N 群に比 べ, H 群では TC, TG が高く, HDL コレステロールが低 いのは当然であるが, 収縮期および㧪張期血圧も高く, body mass index (BMI) も高値を示した。 OVはH 群で $\mathrm{N}$ 群より有意に低值を示したが (Fig. 1， H：0.52士0.14 
Table 1 The clinical background of normal Al group and high $\mathrm{Al}$ group.

\begin{tabular}{|c|c|c|c|c|c|c|c|c|c|}
\hline \multirow{2}{*}{\multicolumn{4}{|c|}{ total }} & \multicolumn{3}{|c|}{ nomal Al group } & \multicolumn{3}{|c|}{ high Al group } \\
\hline & & & & all & men & women & all & men & women \\
\hline & $\mathrm{n}$ & & 145 & 71 & 44 & 27 & 56 & 37 & 18 \\
\hline & AGE & & $50 \pm 11$ & $50 \pm 11$ & $48 \pm 11$ & $52 \pm 12$ & $53 \pm 10^{*}$ & $52 \pm 10$ & $56 \pm 9$ \\
\hline BMI & & $\left(\mathrm{kg} / \mathrm{m}^{2}\right)$ & $23.2 \pm 29$ & $220 \pm 27$ & $21.8 \pm 2.5$ & $224 \pm 29$ & $247 \pm 2.8^{* * *}$ & $247 \pm 2.2^{* * *}$ & $246 \pm 3.6^{*}$ \\
\hline SBP & & $(\mathrm{mmHg})$ & $127 \pm 17$ & $124 \pm 17$ & $124 \pm 17$ & $123 \pm 17$ & $132 \pm 17 * *$ & $133 \pm 18$ & $131 \pm 16$ \\
\hline DBP & & $(\mathrm{mmHg})$ & $76 \pm 12$ & $73 \pm 10$ & $73 \pm 10$ & $72 \pm 11$ & $80 \pm 13^{* *}$ & $82 \pm 13^{* *}$ & $77 \pm 15$ \\
\hline $\mathrm{T}-\mathrm{CHO}$ & & $(\mathrm{mg} / \mathrm{dl})$ & $198 \pm 38$ & $177 \pm 23$ & $174 \pm 23$ & $181 \pm 22$ & $221 \pm 36^{* * *}$ & $223 \pm 33^{* * *}$ & $210 \pm 43^{* *}$ \\
\hline HDL-C & & $(\mathrm{mg} / \mathrm{dl})$ & $54 \pm 13$ & $62 \pm 11$ & $60 \pm 10$ & $65 \pm 11$ & $45 \pm 8^{* * *}$ & $45 \pm 7^{* * *}$ & $45 \pm 10^{* * *}$ \\
\hline $\mathrm{TG}$ & & $(\mathrm{mg} / \mathrm{dl})$ & $126 \pm 77$ & $115 \pm 22$ & $89 \pm 39$ & $74 \pm 31$ & $176 \pm 30^{* * *}$ & $180 \pm 84 * * *$ & $168 \pm 94^{* * *}$ \\
\hline $\mathrm{Al}$ & (TC-HDL & C/HDLC) & $2.84 \pm 109$ & $1.92 \pm 051$ & $195 \pm 0.49$ & $1.87 \pm 0.53$ & $3.95 \pm 0.63^{* * *}$ & $397 \pm 0.62 * * *$ & $3.96 \pm 065^{* * *}$ \\
\hline
\end{tabular}

$\mathrm{Al}$ : atherogenic index ${ }^{*} \mathrm{P}<0.05,{ }^{* *} \mathrm{P}<0.01,{ }^{* * *} \mathrm{P}<0.001$ vs nomal $\mathrm{Al}$, mean $\pm \mathrm{SD}$

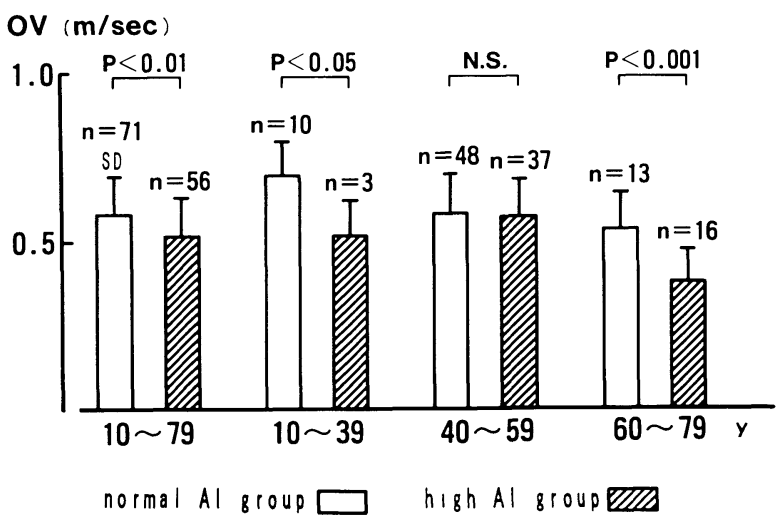

Fig. 1 Comparison of opening velocity between nomal Al group and high $\mathrm{Al}$ group.

vs N : $0.59 \pm 0.12 \mathrm{~m} / \mathrm{sec}, \mathrm{p}<0.01)$, 各年齢層でみると $10-$ 39 歳, 60-79 歳では H 群で低值だったが，40-59 歳では 2 群間で差がなかった (Fig. 1).

全対象者では OV と年齢との間には，全体，男性およ び女性でそれぞれ有意な負の相関関係が認められた (Fig. 2, r $=-0.49,-0.45,-0.58$, 抒の沶の $\mathrm{p}<0.01$ ). ま た, AI 高值群は AI 正常群に比べ加齢に伴う OV 減少の 程度が大きいことが示された (Fig. 3, p<0.05). そこで 各年龄層別に OV と AI, TC, HDL コレステロール, TG および血圧との関係を調べると (Table 2), 40-59歳で は, OVは各種パラメーターと有意な相関関係が認めら れなかったが，10-39歳(男性のみ) と60-79歳では, $\mathrm{OV}$ と AI との間には有意な負の相関関係が認められた。 $\mathrm{OV}$ は TCとの間には有意な相関は認められなかった が，TGとの間には全女性および 60-79歳で負の相関関 係が認められた。OV と血王との関係は, 女性で OV と収 縮期血圧との間に負の相関関係を認められた以外には有 意な相関関係は認められなかった。

同一日に 2 回測定した OV 間には良好な相関関係が認 められた (Fig. 4, r=0.99, p<0.01)。 また，測定日が異な る場合でも良好な相関関係が認められた (Fig. 5, r=
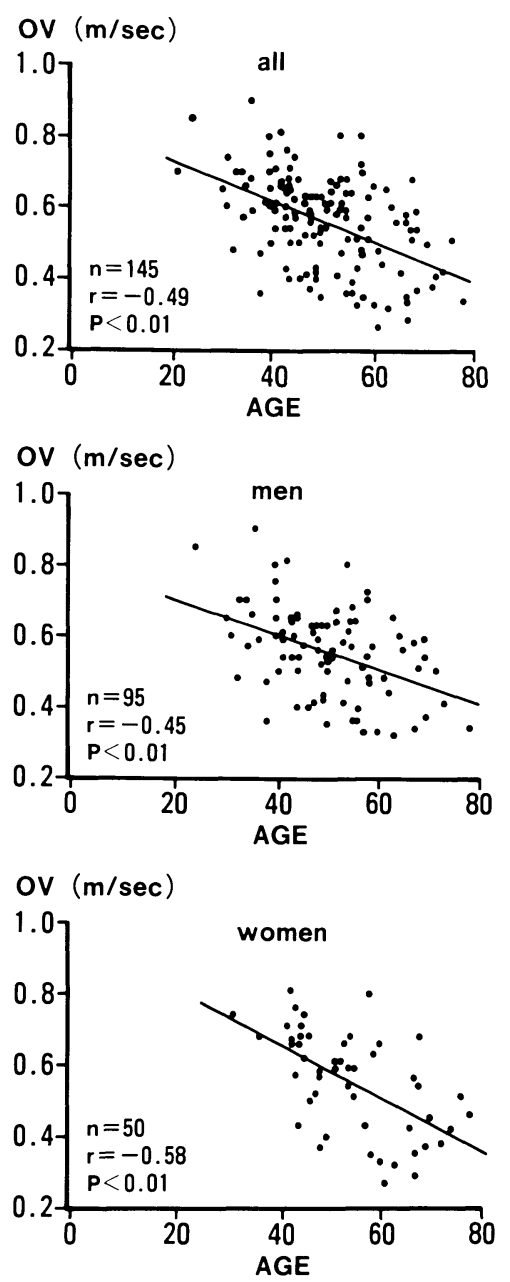

Fig. 2 Correlation between opening velocity and the age of subjects.

$0.89, \mathrm{p}<0.05)$

\section{VI. 考察および結論}

動脈壁血管開口伝播速度 (OV) は，田中および木下 ${ }^{1)}$ により見出された現象であり，加齡に伴い減少すること が示されている2,3). また，われわれも OVが従来より動 


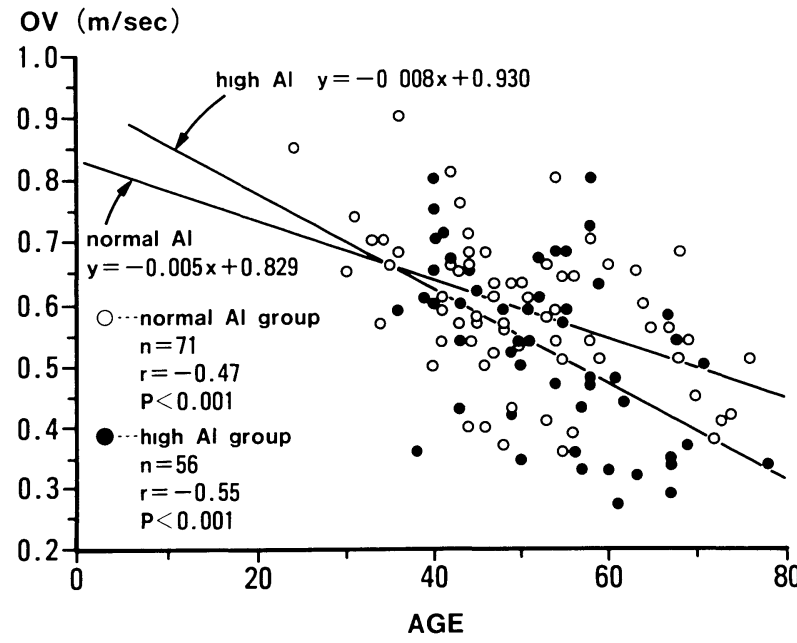

Fig. 3 The best fit regression lines of OV decrease with age in nomal and high $\mathrm{Al}$ groups.

脈硬化の指標として用いられている大動脈脈波伝播速度 $(\mathrm{PWV})$ と負の相関関係を示すこと ${ }^{3)}$ ，また，冠動脈造影 にて冠動脈に有意な狭窄のある患者では正常者と比べ OVが低值であることを報告しており3)，OV は動脈硬化 の新しい指標となる可能性が示唆されている。その再現 性についても同一被験者では, 運動負荷や cold pressor 試験などによる血圧，心拍数の増加による影響を受けな いことも示されている2).

さらに，本研究では異なる日に測定した OV 間に良好 な相関関係が認められたことより，その再現性が良好で あることが確認され，OV は個々の患者で一定した固有 のものと考えられる。

本研究では, OVは (TC-HDL コレステロール)/HDL コレステロールより求めた動脈硬化指数 (AI) 高值群で AI 正常群より低值を示した。また，OV は加齢に伴い減

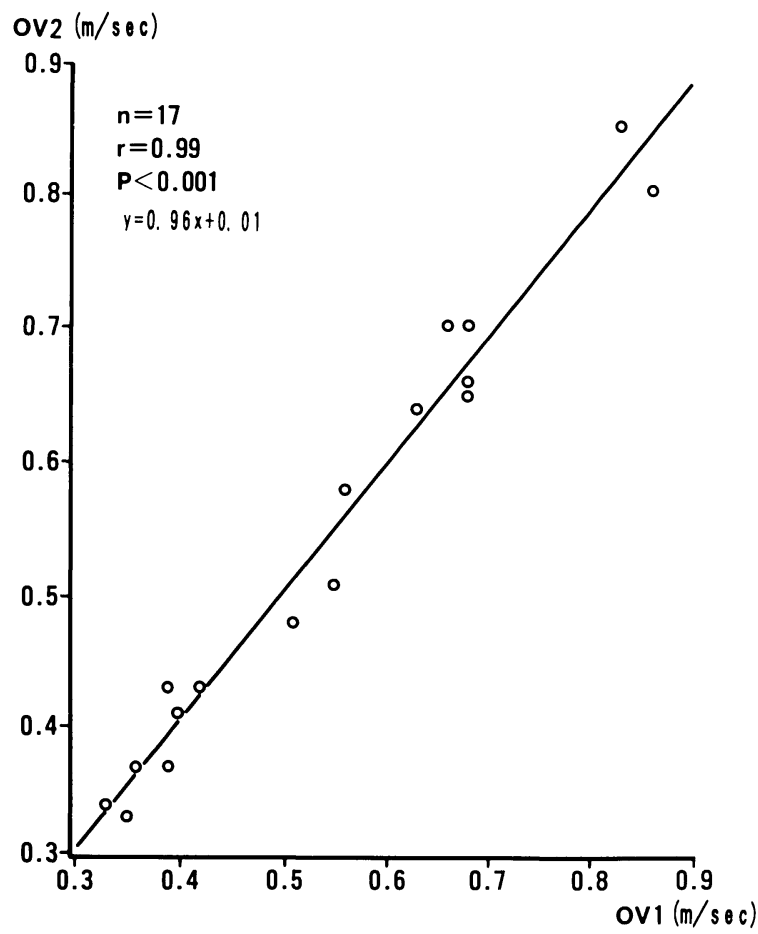

Fig. 4 Correlationship between two measurements of $\mathrm{OV}$ in one day. OV1 : first measurement. OV2 : second measurement.

少して扣り，OV と AI との関係を年齡別に検討した結果 では, OV と AI とは 40-59 歳では相関関係がなく, 60-79 歳で負の相関関係が認められた。その理由は不明である が，次のような可能性が考えられる。すなわち，AI は動 脈硬化の程度を示すものではなく，その高值は動脈硬化 発症, 進展の危険因子と考兄られるので, たとえ AI が高 值でも動脈硬化発症進展までには一定の年月を要するも のと思われる。また，脂質異常は若年者より発症した家 族性高脂血症のものを除くと中年以降の発症が多く，高

Table 2. Correlation coefficient ( $\mathrm{r}$ ) between opening velocity (ov) and lipids or blood pressure in age grouped subjects.

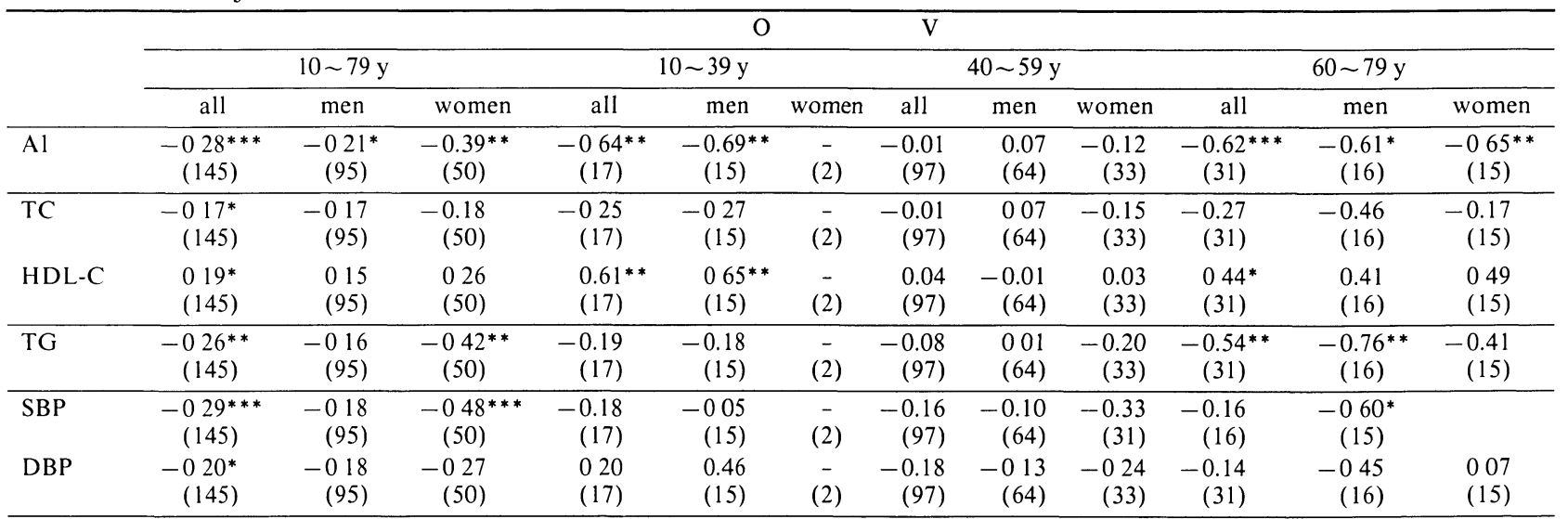

upper : Pearson's correlation coefficient, lower : $(\mathrm{n}),{ }^{*} \mathrm{P}<0.05,{ }^{*}{ }^{*} \mathrm{P}<0.01,{ }^{* * *} \mathrm{P}<0.001$ 


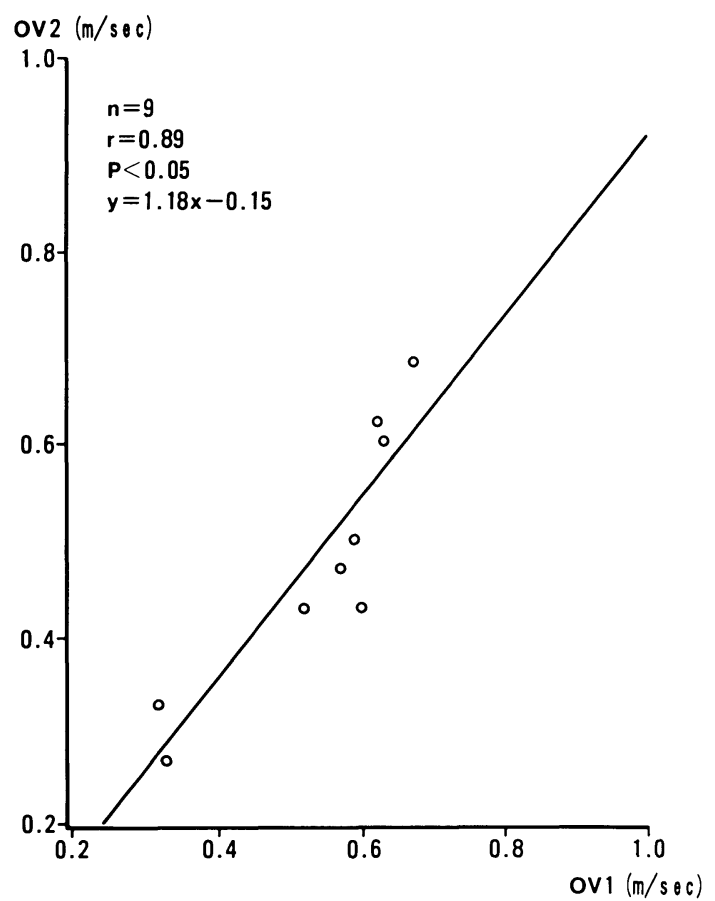

Fig. 5 Correlationship between two measurements of $\mathrm{OV}$ in separate days.

齢になると高脂血症 (AI 高値) の期間も十分となり動 脈硬化症が認められるものと考兄られる。すなわち, 本 研究の成績では 60-79歳では, AI 高值のもので OV が低 值を示しており，OVを動脈硬化の指標と考劣るならば $\mathrm{AI}$ 高值のもので動脈硬化が進んでいるとも考兄られる。

10-39 歳 (泀とんど男性) では, AI 高値群で OVは低 值を示した。若年者とい党ども家族性高脂血症では，冠 動脈疾患を発症する頻度が高く ${ }^{4)}$, 全身の粥状硬化も進 んでいるものと考光られて括り, 本研究で対象とした若 年高脂血症 (AI 高値) 患者には家族性高コレステロー ル血症のものが多く含まれたためとも考兄られるが, AI 高値の若年者数が 3 例と少なく，十分な検討ができな かったため本成績については今後の検討が必要である。

AI 高值群と AI 正常群とに分けて加齢と OV との関 係を調べると, OV の加齢に伴う減少は AI 高值群が $\mathrm{AI}$ 正常群より大きく，OV が動脈硬化度を示するのである
ならば, $\mathrm{AI}$ 高値はその増悪因子となりらるものと考兄ら れる。

また，全年齢で OV と脂質との関係をみると，女性の みで OV と TG との相関関係が認められた。すなわち,女 性では，男性に比べ特に TG 高値が動脈硬化の危険因子 となる可能性が示唆された。

動脈壁血管開口伝播速度は同一被験者に打いて異なる 日に測定しても再現性は良好であり，各個人に特有の值 を示す指標である。全体抢よび 60-70歳代の高齢者で動 脈壁血管開口伝播速度は AI 高值のもので低值を示して おり，OVのすでに報告した加齢に伴う減少 ${ }^{2,3)}$ や冠動脈 狭窄患者での低值 ${ }^{3)}$, 大動脈脈波伝播速度と相関関係を 示すこと3)などを考兄合わせると，動脈壁血管開口伝播 速度は動脈硬化の指標となりらると考兄られる。動脈硬 化検查法には golden standard がないので, 今後, 動脈造 影, CT, エコーなどを用いた検査法とも比較する必要が あろら。また一般に上腕動脈の粥状硬化はまれであると の報告もあるので，OV と上腕動脈組織変化との関係に ついても検討することが重要である。しかし，OV 測定は 非侵襲的検査法であり, 間接法による血圧測定を 2 3 回 行う位の短時間で測定でき, 測定器がどこへでも移動で さる簡便さもあり，新しい動脈硬化度検査法の一つとし て有用であると考觉らる。

\section{文献}

1) 田中 博，木下重博：間接法血圧測定時に和ける動 脈血管壁開口伝播現象の非侵襲計測。脈管学 $\mathbf{3 0}$ : 1371-1378, (1990)

2) 田中 博 他：間接法血圧測定に抢ける血管壁開口 伝播速度の収縮期血圧および血管運動神経活動に対 する非依存性と年齢相関性について。日本臨床生理 学会雑誌 21：189-197, (1991)

3）美並真由美 他：血管粘弾性の新しい非侵襲的測定 法一動脈壁血管開口伝播速度の冠動脈狭窄患者での 測定㧍よび脈波伝播速度との関係 (abstruct)。動脈 硬化 19：512, (1991)

4) Mabuchi $\mathrm{H}$ et al: Development of coronary heart disease in familial hypercholesterolemia. Circulation 79: 225-332, (1989) 


\title{
Summary
}

\section{Opening Propagation Velocity of the Collapsed Brachial Artery as a New Noninvasive Means of Arteriosclerosis Evaluation : Relationship to Serum Lipids and Atherogenic Index}

\author{
Keiichiro Atarashi, Mayumi Minami, Masao TaKagi, \\ Akihiro Ishiyama, Fumiyoshi Watanabe, Katsu Takenaka, \\ and Masao Omata
}

The 2nd Department of Internal Medicine, Faculty of Medicine, the University of Tokyo

Measurement of opening velocity (OV) of the collapsed brachial artery has been suggested as a new noninvasive method of evaluating arteriosclerosis. We therefore examined the relationship between OV and either serum lipids or atherogenic index (AI) in 145 subjects (95 men and 50 women).

Repeated measurements of OV in one day suggested that $\mathrm{OV}$ values for individual subjects remained constant. OV was negatively correlated with age $(\mathrm{r}=-0.49, \mathrm{p}<0.01)$. Although a highly significant correlation between $\mathrm{OV}$ and AI or serum lipids was not observed in all subjects, there were negative correlations between $\mathrm{OV}$ and AI or serum triglyceride level in subjects aged $60-79$ years. In order to examine the effect of AI level on OV, we divided subjects into a high $\mathrm{AI}(\mathrm{AI} \geqq 3.2)$ group $(\mathrm{H}, \mathrm{n}=56)$ and normal $\mathrm{AI}(\mathrm{AI} \leqq 2.8)$ group $(\mathrm{N}, \mathrm{n}=71)$ based on AI levels from at least 2 separate measurements. OV was lower in the $\mathrm{H}$ group than in $\mathrm{N}(0.52 \pm 0.14$ vs $0.59 \pm 0.12 \mathrm{~m} / \mathrm{sec}, \mathrm{p}<0.01)$. Also, the regression line for OV reduction with age had a steeper slope for group $\mathrm{H}$ than $\mathrm{N}(\mathrm{p}<0.05)$.

The results suggest tnat $\mathrm{OV}$ measurement is a useful noninvasive method of evaluating arteriosclerosis.

Key words : Opening velocity, Atherogenic index, Arteriosclerosis, Noninvasive. 